\title{
Heading south: new records of the invasive quagga mussel Dreissena rostriformis bugensis (Andrusov, 1897) in France and further perspectives
}

\author{
Vincent Prié ${ }^{1, *}$ and Jean-François Fruget ${ }^{2}$ \\ ${ }^{1}$ Biotope, 22 Bd Maréchal Foch, BP58, 34140 Mèze, France \\ 2 ARALEP Campus LyonTech - La Doua, Bât CEI 1, 66 Bld Niels Bohr CS 52132, 69603 Villeurbanne Cedex, France
}

\begin{abstract}
Intensive malacological surveys coupled with environmental DNA analyses in France has led to the discovery of new populations of the quagga mussel Dreissena rostriformis bugensis (Andrusov, 1897), an introduced and invasive freshwater bivalve species. Molecular analyses confirmed the identification of the species based on a barcoding approach using both CO1 and 16S genes fragments. Discovered in 2011 in the rivers of north-east France, the quagga Mussel has now colonized the Rhône drainage. This advance represents not only the colonization of a new coastal drainage (the Rhône Rivers flows to the Mediterranean side of France), but also a spectacular 400-km leap south of its previously known range. Further expansion routes provided by canals between main coastal drainages are discussed. For the first time, we propose to use environmental DNA to assess absence, thus paving the way for future freshwater invasive species monitoring methods.
\end{abstract}

Keywords: invasive species / freshwater mussel / environmental DNA / absence data / colonization route

Résumé - Cap au sud: nouvelles données sur la moule quagga Dreissena rostriformis bugensis (Andrusov, 1897) envahissante en France et perspectives futures. Des inventaires malacologiques intensifs, couplés à l'analyse de l'ADN environnemental, ont conduit à la découverte de nouvelles populations de Moules quagga Dreissena rostriformis bugensis (Andrusov, 1897), une espèce de bivalve dulçaquicole introduite et envahissante. Des analyses moléculaires basées sur une approche de type «barcoding» ont confirmé l'identification de l'espèce en utilisant des fragments des gènes COI et 16S. Découverte en 2011 dans les rivières du nord-est de la France, la Moule quagga a désormais colonisé le bassin versant du Rhône. Cette progression représente non seulement la colonisation d'un nouveau bassinversant côtier (le Rhône coule vers la mer méditerranée), mais aussi un bond spectaculaire de $400 \mathrm{~km}$ au sud de son aire de répartition connue précédemment. Les potentielles routes de colonisation future, via les canaux, sont discutées. Pour la première fois, nous proposons d'utiliser l'ADN environnemental pour démontrer l'absence, ouvrant la voie à des méthodes d'avenir pour le suivi des espèces dulçaquicoles envahissantes.

Mots-clès : espèce envahissante / moule d'eau douce / ADN environnemental / données d'absence / voie de colonisation

\section{Introduction}

Non-indigenous invasive species are one of the most important threats to biodiversity and ecosystems (Carlton and Geller, 1993; Sala et al., 2000; Cox, 2004). Freshwater ecosystems are particularly impacted by these invasive species (Lodge et al., 1998; Orr, 2003). Among freshwater invertebrates, freshwater bivalve species are being introduced

\footnotetext{
${ }^{*}$ Corresponding author: vprie@biotope.fr
}

worldwide at an increasing rate, mainly because of human activities (Darrigran, 2002; Karatayev et al., 2007). In France alone, nine species of freshwater bivalves have been introduced: Mytilopsis leucophaeata (Conrad, 1831) from 1835, Dreissena polymorpha (Pallas, 1771) since 1852, Corbicula fluminea (O.F. Müller, 1774), Corbicula fluminalis (O.F. Müller, 1774) and Corbicula leana Prime, 1867 since the 80s (although taxonomic issues are controversial, leading to a doubt regarding the introduction dates) (Mouthon, 1981; Pigneur et al., 2011; Hesse et al., 2015), Sphaerium 
transversum (Say, 1829) since 1984, Sinanodonta woodiana (Lea, 1834) since 1982 (Mouthon, 2008; Adam, 2010), Euglesa compressa (Prime, 1852) since about 2010 (Mouthon and Forcellini, 2017) and Dreissena rostriformis bugensis (Andrusov, 1897) since 2011 (Bij de Vaate and Beisel, 2011; Marescaux et al., 2015). Introduction processes are likely going on nowadays. But the lack of taxonomists and field malacologists makes invasive species detection challenging. Ecosystems invasions may be overlooked, especially when the species involved are similar in shell shape to those preexisting; or when they live in hard to survey environments such as downstream ecosystems of large rivers.

The zebra mussel $D$. polymorpha is a common species in France. Generally abundant, widespread and of no conservation concern, the zebra mussel does not attract naturalists' attention. The quagga mussel D. rostriformis bugensis is similar in shell shape and lives in the same habitats. It has been noticed in France for the first time in 2011 (Marescaux et al., 2012). It is likely that the quagga mussel's expansion in France has remained unnoticed or overlooked for the last decade.

This note presents new data about the ongoing invasion of the quagga mussel in France and discusses its potential distribution for now and tomorrow.

\section{Material and methods}

\subsection{Data collection}

Data comes from environmental DNA (eDNA, Taberlet et al., 2012) samples, as already been used for detecting Dreissena species (Lance and Carr, 2012; De Ventura et al., 2017); direct observation during scuba-diving malacological surveys; and dredging of sediment. Water samples were analyzed by SpyGen ${ }^{\circledR}$ for eDNA extraction, amplification and sequencing (for details on this unpublished protocol, see the methods developed by Valentini et al., 2016 for fishes and amphibians; and for freshwater bivalves, await Prié et al., in prep.). Direct observation in scuba diving involved four divers during five days in the Saône River and allowed taking pictures in the field and collecting specimens by hand. The collected specimens were then processed in the lab and flesh samples were extracted, amplified and sequenced by Eurofins ${ }^{\circledR}$. Dredging was performed in the Rhône main channel using a boat and a standard triangular dredge. Collected sediment samples were curated in the lab.

\subsection{Data location}

Data presented here comes from the Vignoble Lake (Escaut coastal drainage) and the Saône River (Rhône coastal drainage), respectively in 2015 using environmental DNA and in 2016 using environmental DNA and with direct observation during a malacological survey. Locations and collection date were as follows:

- Vignoble Lake, 50.341667 N, 3.499510 E, 07/09/2015,

Environmental DNA, sampling X. Cucherat, identification V. Prié (Biotope);

- Saône River, Pontaillier-sur-Saône, 47.305809N, 5.420149 E, 19/07/2016, direct observation during scuba-diving survey, collection and identification V. Prié (Biotope);
- Saône River, Maillys, 47.125213 N, 5.339523 E, 19/07/ 2016, direct observation during scuba-diving survey, collection and identification V. Prié (Biotope);

- Saône River, Tillenay, 47.188770 N, 5.365820 E, 19/07/ 2016, direct observation during scuba-diving survey, collection and identification V. Prié (Biotope);

- Saône River, 47.275757 N, 5.389430 E, 19/07/2016, direct observation during scuba-diving survey, collection and identification V. Prié (Biotope);

- Saône River, Pontaillier-sur-Saône, 47.305562 N, 5.419387 E, 19/07/2016, environmental DNA, sampling and identification V. Prié (Biotope);

- Saône River, Maillys, 47.125214 N, 5.339523 E, environmental DNA, sampling and identification V. Prié (Biotope);

- Rhône River, Chavanay, 45.416863 N, 4.743379 E, 12/04/ 2016-28/06/2016-01/09/2016-26/10/2016, sediment sampling in the deep main channel with triangular dredge, collection J.F. Fruget (Aralep), identification Jeanne Dessaix (Aralep);

- Rhône River, Saint-Rambert-d'Albon, 45.298781 N, 4.805102 E, 12/04/2016-07/07/2061-01/09/2016-25/10/ 2016, sediment sampling in the deep main channel with triangular dredge, collection J.F. Fruget (Aralep), identification Jeanne Dessaix (Aralep);

- Rhône River, Arcoules, by-passed section, 45.358505 N, 4.767272 E, 13/04/2016-07/07/2016-02/09/2016-03/11/ 2016, sediment sampling with triangular dredge, collection J.F. Fruget (Aralep), identification Jeanne Dessaix (Aralep).

\subsection{Species identification}

In the Saône and Rhône Rivers, the specimens were identified in the field by their shell morphology which combined the following diagnostic characters: asymmetry of the shell valves as seen from the ventral view, byssus located near the hinge (Fig. 1A); periostracum dark brown with no zebra lines (Fig. 1B); rounded ventral margin with no acute ventrolateral ridge or carina (Fig. 1C), which are the main differences with the zebra mussel; absence of apophysis (Fig. 1D), which is the main difference with $M$. leucophaeata. Live specimens were noticed first by their remarkably long siphon (Fig. 1E). All these morphological characters correspond to quagga mussel description (Pathy and Mackie, 1993; Sablon et al., 2010).

Five specimens were sampled and COI gene fragments were amplified using standard protocols (e.g. Prié et al., 2012) for barcoding purpose (GenBankaccession numbers MF469063, MF469064, MF469065). Additionally, 16S eDNA sequence fragments were amplified from samples collected in the Saône River and Vignoble Lake. COI fragments from live specimens and $16 \mathrm{~S}$ fragments from eDNA were aligned with available sequences mined from GenBank using BioEdit 7.2.5 (Hall, 1999).

\subsection{Taxonomy}

The use of the names $D$. rostriformis (Deshayes, 1838) or $D$. bugensis (Andrusov, 1897) for the introduced quagga mussel has been controversial (Stepien et al., 2003; Rosenberg and Huber, 


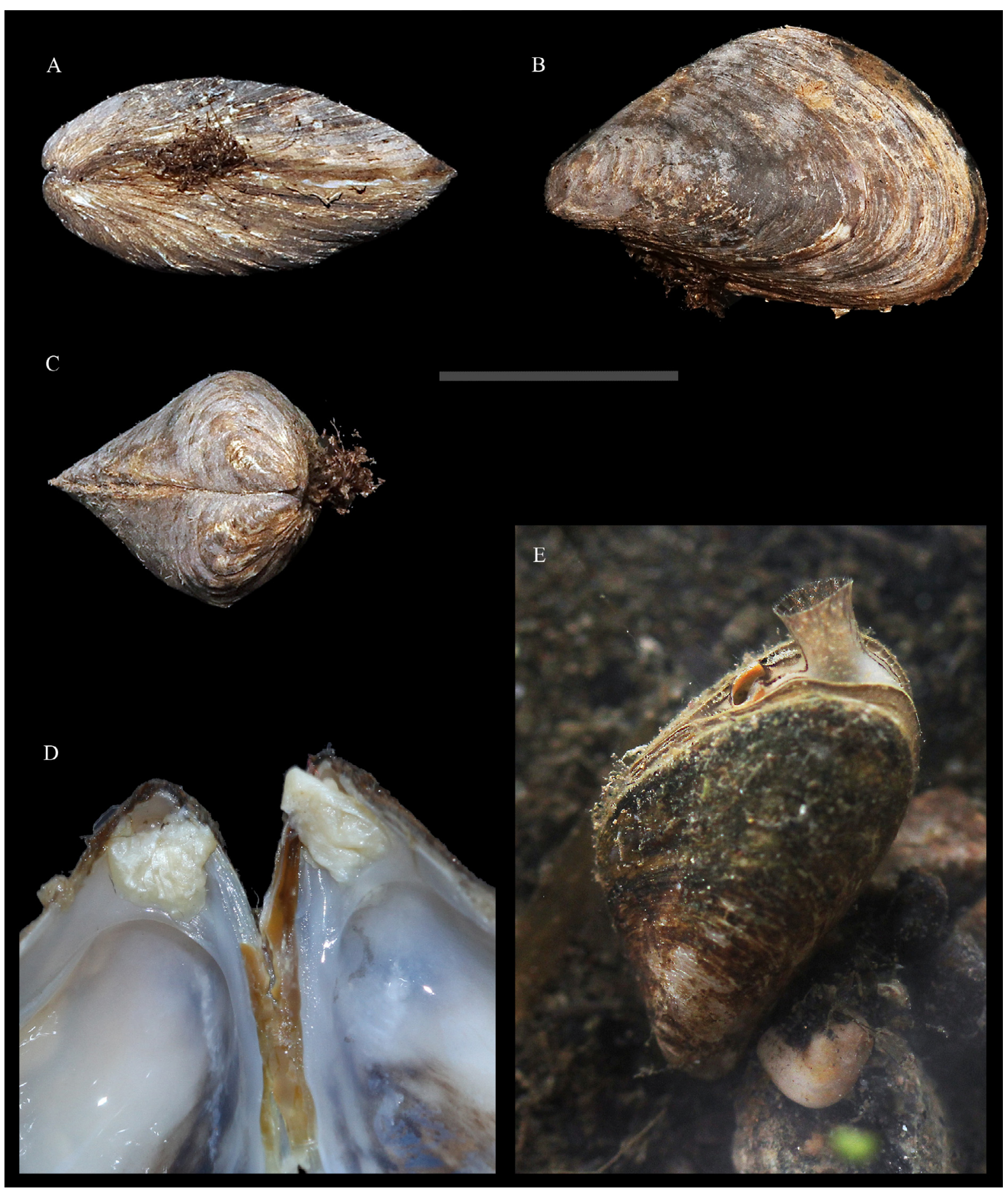

Fig. 1. Dreissena rostriformis live specimen collected in the Saône River in 2016. (A) Ventral view showing the asymmetric shell shape and the position of the byssus; (B) lateral view, left valve, with no zebra lines pattern; (C) frontal view showing the diagnostic rounded shell edges; D: zoom on the hinge; E: a living specimen in the Saône River, with long siphon extended. Scale bar: $20 \mathrm{~mm}$ (D and E not to scale).

2012; Bieler et al., 2015). These nominal species are here considered as synonyms following the conclusions of the molecular phylogenies established by Therriault et al. (2005) and Stepien et al. (2014). According to the principle of priority, the name $D$. rostriformis should then be applied to the quagga mussel. However, the nominal subspecies
D. rostriformis rostriformis is a marine deep-water mussel which is not known to be an invader and remains endemic to the Caspian Sea. The invasive quagga mussel is believed to be a descendant which evolved in the isolated Black Sea. The Black Sea had a freshwater period, possibly leading to an ecological adaptation of its quagga mussel population. Indeed, the quagga 
mussel found today in Europe lives in a different range of salinity. It is therefore arguable that the European quagga mussel could be considered a distinct species. However, we lack reproduction experiments as both clade cannot be acclimated to a common salinity level. Given the taxonomic uncertainty, and even if this is not satisfactory, we here refer to the European quagga mussel as D. rostriformis bugensis.

\section{Results}

\subsection{Presence data}

In the Vignoble Lake, we have no direct observation of quagga mussels and only eDNA revealed its presence, together with the zebra mussel. In the Saône River, the species was abundant. Live specimens have been seen in every surveyed site between Pontailler-sur-Saône and Maillys (Fig. 2), mixed with $D$. polymorpha. Individuals were always fixed to substrate (pebbles, stones and rocks) and sometimes to another freshwater mussel species (most often Potomida littoralis). Southwards in the Rhône, live specimens were found in the sediment collected in the main channel by dredging. Hundreds of specimens were collected from a substrate of pebbles and gravels, suggesting the species has reached the lower Rhône since many generations. eDNA samples do not allow quantification of the species occurrence, but amplified fragments were very abundant in all sample sites.

\subsection{Absence data}

Based on previous tests comparing the effectiveness of eDNA surveys to traditional methods (Prié et al., in prep.), we showed that the eDNA detection method is very accurate for freshwater bivalves. We consider it is trustful enough to be used for absence assessment. Since 2015, eDNA samples were collected from various places in France, in the Rhône, Loire drainages and in Mediterranean coastal rivers (Fig. 2). None revealed quagga mussel eDNA fragments.

Malacological investigations in Cruas and Tricastin in the lower section of the Rhône, using traditional methods accurate enough for the detection of the species, did not allowed finding any quagga mussels either. We therefore consider the species as absent from these places for now.

\section{Discussion}

\subsection{Historical data}

The quagga mussel $D$. rostriformis is native from the Caspian Sea; the subspecies D. rostriformis bugensis being considered as coming from the Dniepr and Bug deltas in the Black Sea (Orlova et al., 2004; Son, 2007). Its first expansion into rivers dates back to the years 1940-1990: to the north along the Dnieper River; to the East through the Don River and then on to the Volga River; and to the north-east through the Dniester River (Orlova et al., 2004; Woźniczka et al., 2016). The quagga mussel has colonized western Europe only recently: it was recorded in the lower part of the Danube River only in 2004 (Micu and Telembici, 2004). The Danube is a key river for the European southern invasion corridor, being

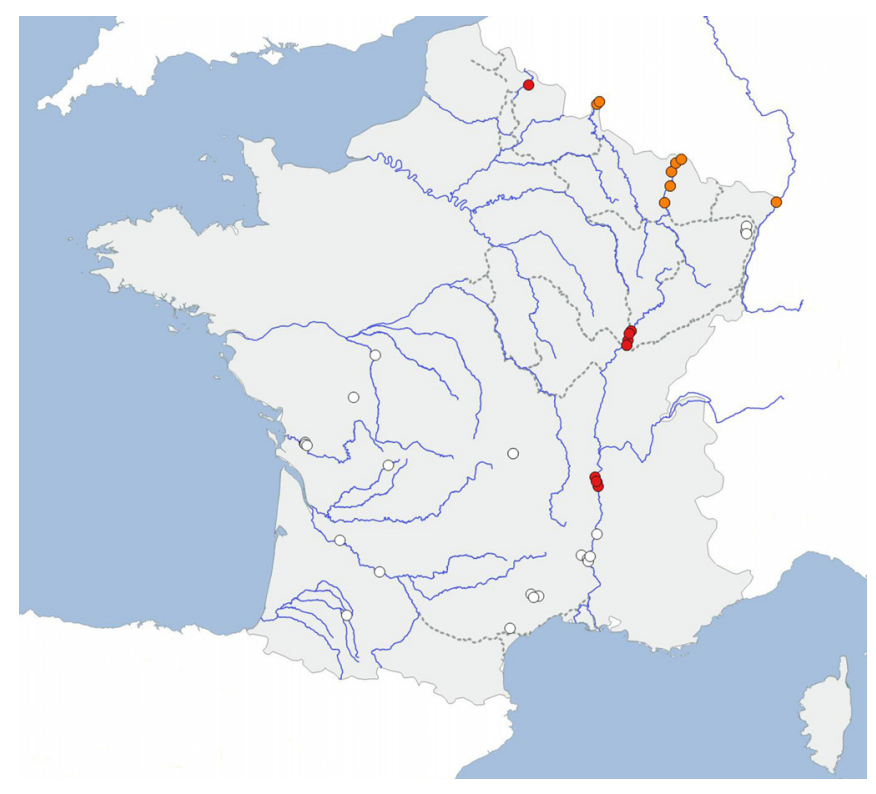

Fig. 2. D. rostriformis data in France. Bluelines: main rivers; gray dotted lines: canals; orange dots: data 2011-2014; red dots: data from 2015; white dots: absence data 2015-2017.

connected to the Rhine basin (Panov et al., 2009; Leuven et al., 2009), and from there to almost all major coastal drainages in France via canals. The species has probably spread very rapidly from the early 21 st century, as it was first observed in the Rhine River in Netherlands in 2004 too (Imo et al., 2010; Heiler et al., 2013), then in the Dutch section of the Meuse River in 2007 (Marescaux et al., 2012) and in the Albert Canal, which connects the Meuse River, in Belgium in 2009 (Sablon et al., 2010). Not surprisingly, the species was observed in the French section of the Meuse and Moselle Rivers in 2011 (Bij de Vaate and Beisel, 2011; Marescaux et al., 2012); and in the French section of the Rhine River in 2014 (Wagner, 2014). We here observe an important extension in two more River drainages, the Escaut, which is close and directly connected to the Meuse River drainage; and a lot further south in the Rhône River drainage, first record of occurrence in a Mediterranean drainage occurrence in France (Fig. 2). This significant leap augurs a further extension in most French drainages.

\subsection{Existing colonization routes in France and future perspectives}

Coastal drainages' geographical isolation is a driving force of genetic drift and subsequent speciation processes. Today's human development, with the establishment of canals, tends to mix up previously isolated faunas. Artificial connections between coastal drainage systems provide a serendipitous opportunity for invasive species to spread out of their introduction localities.

The quagga mussel displays a more important invasive potential than the zebra mussel. Replacement of zebra mussel by quagga mussel is now well documented, having been observed at several locations in its initial expansion routes 


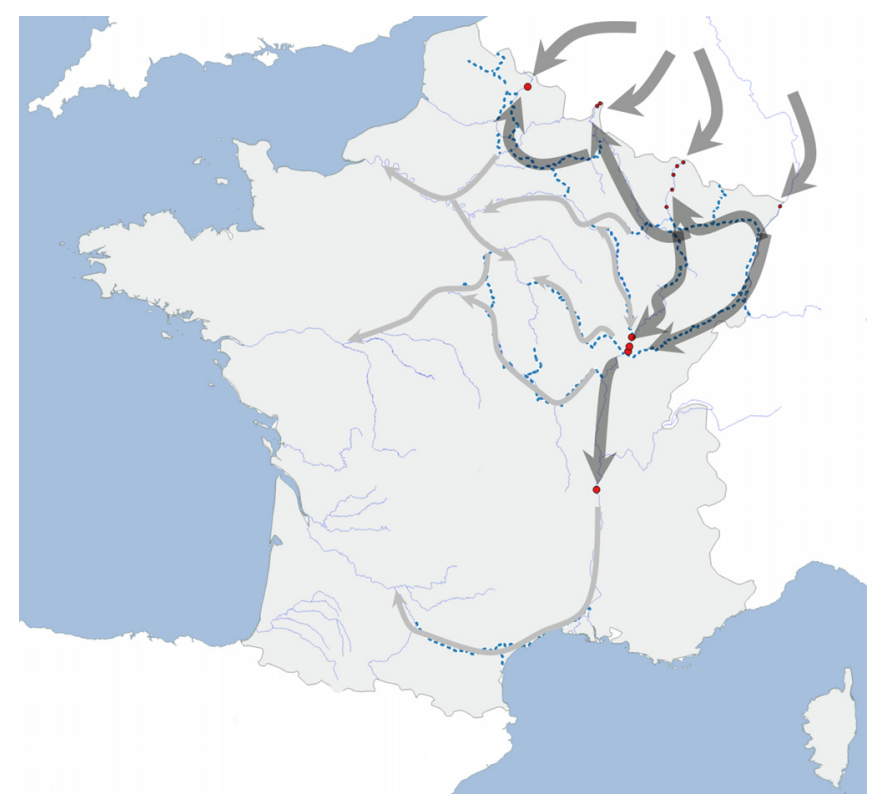

Fig. 3. Potential past and future expansion corridors. Blue lines: main French rivers; blue dotted lines: canals; small dots: data before 2014; large dots: data after 2014; large arrows: possible past expansion ways; thin arrows: possible future expansion ways.

around the Black Sea (Dniepr, Don, Volga) as well as in Europe (Marescaux et al., 2015) and northern America (e.g. Stoeckmann, 2003; Wilson et al., 2006; Ram et al., 2011; Stewart, 2014). We can therefore expect an important expansion of the quagga mussel population in the Rhône drainage, including its tributaries, but also in the adjacent drainages: canals provide artificial pathways from the Rhône to the Seine, Loire and Garonne drainages (Fig. 3).

\section{Conclusion}

Zebra mussels are introduced in France for a long time, are common where they occur, and naturalists do not pay attention to them. The similar-shaped quagga mussel was observed for the first time in north-eastern French Rivers in 2011. It has probably spread out slowly to adjacent watercourses using canals, but has been overlooked. We here synthetize its current distribution in France based on direct observation and eDNA studies. Actual distribution is probably much wider than what sparse data suggest. Existing pathways via canals suggest the quagga mussel can colonize the main French drainages in a near future.

Hydrobiologists from central and western France should watch out: if not yet there, quagga mussels may arrive in the next few years.

Acknowledgments. Benjamin Adam, Xavier Cucherat, Nicolas Legrand, Laurent Philippe, Nicolas Patry, Lucas Berenger (Biotope), Jeanne Dessaix (Aralep), Tony Déjean, Alice Valentini, Pauline Jean (SpyGen). This work was conducted within the scope of the LIFE project "Life13BIOFR001162 Conservation of the Giant Pearl Mussel in Europe". We also thank an anonymous reviewer for valuable comments about the quagga mussel's taxonomy and origins.

\section{References}

Adam B. 2010. L'Anodonte chinoise Sinanodonta woodiana (Lea, 1834) (Mollusca, Bivalvia, Unionidae) : une espèce introduite qui colonise le bassin Rhône-Méditerranée. MalaCo 6: 278-287.

Bieler R, Rosenberg G, Huber M. 2015. Dreissena bugensis. In: MolluscaBase (2016). World Register of Marine Species. Available from http://www.marinespecies.org/aphia.php? $\mathrm{p}=$ taxdetails\&id= 505319 (accessed on: 2017/03/06).

Bij de Vaate A, Beisel J-N. 2011. Range expansion of the quagga mussel Dreissena rostriformis bugensis (Andrusov, 1897) in Western Europe: first observation from France. Aquat Invasions 6 (Suppl. 1): 71-74.

Carlton JT, Geller JB. 1993. Ecological roulette: the global transport of non-indigenous marine organisms. Science 261: 78-82.

Cox GW. 2004. Alien species and evolution. Washington, USA: Island Press, $377 \mathrm{p}$.

Darrigran G. 2002. Potential impact of filter-feeding invaders on temperate inland freshwater environments. Biol Invasions 4: 145-156.

De Ventura L, Kopp K, Seppälä K, Jokela J. 2017. Tracing the quagga mussel invasion along the Rhine river system using eDNA markers: early detection and surveillance of invasive zebra and quagga mussels. Manag Biol Invasions 8(1): 101-112.

Hall TA. 1999. BioEdit: a user-friendly biological sequence alignment editor and analysis program for Windows 95/98/NT. Nucleic Acid Symp Ser 41: 95-98.

Heiler KCM, Bij de Vaate A, Ekschmitt K, von Oheimb PV, Albrecht C, Wilke T. 2013. Reconstruction of the early invasion history of the quagga mussel (Dreissena rostriformis bugensis) in Western Europe. Aquat Invasions 8: 53-57.

Hesse A-S, Bérenger M, de Vannoise V, Mangot S. 2015. Historique de propagation de la corbicule, Corbicula fluminea (Bivalvia: Corbiculidae), en région Centre - Val de Loire (France). MalaCo 11: 6-13.

Imo M, Seitz A, Johannesen J. 2010. Distribution and invasion genetics of the quagga mussel (Dreissena rostriformis bugensis) in German rivers. Aquat Ecol 44: 731-740.

Karatayev AY, Padilla DK, Minchin D, Boltovskoy D, Burlakova LE. 2007. Changes in global economies and trade: the potential spread of exotic freshwater bivalves. Biol Invasions 9: 161-180.

Lance RF, Carr MR. 2012. Detecting eDNA of Invasive Dreissenid Mussels: Report on Capital Investment Project, ERDC/TN ANSRP-12-2, $12 \mathrm{p}$.

Leuven RSEW, van der Velde G, Baijens I, et al. 2009. The river Rhine: a global highway for dispersal of aquatic invasive species. Biol Invasions 11: 1989.

Lodge DM, Stein RA, Brown KM, et al. 1998. Predicting impact of freshwater exotic species on native biodiversity: challenges in spatial scaling. Aust J Ecol 23: 53-67.

Marescaux J, Molloy DP, Giamberini L, Albrecht C, Van Doninck K. 2012. First records of the quagga mussel, Dreissena rostriformis bugensis (Andrusov, 1897), in the Meuse River within France. BioInvasions Rec 1(4): 273-276.

Marescaux J, Boets P, Lorquet J, Sablon R, Van Doninck K, Beisel J-N. 2015. Sympatric Dreissena species in the Meuse River: towards a dominance shift from zebra to quagga mussels, Aquat Invasions 10(3): 287-298.

Micu D, Telembici A. 2004. First record of Dreissena bugensis (Andrusov 1897) from the Romanian stretch of river Danube. In: Abstracts of the International Symposium of Malacology, August 19-22, 2004, Sibiu, Romania. 
Mouthon J. 1981. Sur la présence en France et au Portugal de Corbicula (Bivalvia, Corbiculidae) originaire d'Asie. Basteria 45 (4/5): 109-116.

Mouthon J. 2008. Découverte de Sinanodonta woodiana (Lea, 1834) (Bivalvia : Unionacea) dans un réservoir eutrophe : le Grand Large en amont de Lyon (Rhône, France). MalaCo 5: 241-243.

Mouthon J, Forcellini M. 2017. Genetic evidence of the presence in France of the North American species Euglesa compressa Prime, 1852, (Bivalvia, Sphaeriidae). BioInvasions Rec 6.

Orlova MI, Muirhead J, Antonov PI, et al. 2004. Range expansion of quagga mussels Dreissena rostriformis bugensis in the Volga River and Caspian Sea basin. Aquat Ecol 38(4): 561-573.

Orr R. 2003. Generic nonindigenous aquatic organisms risk analysis review process. In: Ruiz GM, Carlton JT, eds. Invasive species: vectors and management strategies. Washington, USA: Island Press, pp. 415-431.

Panov VE, Boris G, Alexandrov BG, et al. 2009. Assessing the risks of aquatic species invasions via European Inland Waterways: from concepts to environmental indicators. Integr Environ Assess Manag 5(1): 110-126.

Pathy DA, Mackie GL. 1993. Comparative shell morphology of Dreissena polymorpha, Mytilopsis leucophaeata and the "quagga" mussel (Bivalvia: Dreissenidae) in North America. Can J Zool 71: 1012-1023.

Pigneur LM, Marescaux J, Roland K, Etoundi E, Descy J-P, Van Doninck K. 2011. Phylogeny and androgenesis in the invasive Corbicula clams (Bivalvia, Corbiculidae) in Western Europe. BMC Evol Biol 11: 147.

Prié V, Puillandre N, Bouchet P. 2012. Bad taxonomy can kill: molecular reevaluation of Unio mancus Lamarck, 1819 (Bivalvia: Unionidae) and its accepted subspecies. Knowl Manag Aquat Ecosyst 405: 8 .

Ram JL, Karim AS, Banno F, Kashian DR. 2011. Invading the invaders: reproductive and other mechanisms mediating the displacement of zebra mussels by quagga mussels. Int $J$ Invertebr Reprod Dev 56: 21-32.

Rosenberg G, Huber M. 2012. Dreissena rostriformis (Deshayes, 1838). In: MolluscaBase. 2016. World Register of Marine Species. Available from http://www.marinespecies.org/aphia.php?p=taxde tails\&id=241216 (accessed on: 2017/03/06).

Sablon R, Vercauteren T, Jacobs P. 2010. De quaggamossel (Dreissena rostriformis bugensis (Andrusov, 1897)), een recent gevonden invasieve zoetwatermossel in Vlaanderen. Antenne 4: $32-36$.
Sala OE, Chapin FS, Armesto JJ, et al. 2000. Global biodiversity scenarios for the year 2100. Science 287: 1770-1774.

Son M-O. 2007. Native range of the zebra mussel and quagga mussel and new data on their invasions within the Ponto-Caspian Region. Aquat Invasions 2: 174-184.

Stepien CA, Taylor CD, Grigorovich IA, et al. 2003. DNA and systematic analysis of invasive and native dreissenid mussels: is Dreissena bugensis really D. rostriformis? Aquat Invaders 14(2): $1-10$.

Stepien CA, Grigorovich IA, Gray MA, Sullivan TJ, Yerga-Woolwine S, Kalayci G. 2014. Evolutionary, biogeographic, and population genetic relationships of Dreissenid mussels, with revision of component taxa. In: Nalepa TF, Schloesser DW, eds. Quagga and zebra mussels: biology, impacts, and control, 2nd ed. Boca Raton: CRC Press, pp. 403-444.

Stewart KM. 2014. Replacement of zebra mussels by quagga mussels in the Erie Canal, New York, USA. In: Nalepa TF, Schloesser DW, eds. Quagga and zebra mussel: biology, impacts, and control, 2nd ed. Boca Raton: CRC Press, pp. 55-64.

Stoeckmann A. 2003. Physiological energetics of Lake Erie dreissenid mussels: a basis for the displacement of Dreissena polymorpha by Dreissena bugensis. Can J Fish Aquat Sci 60: 126-134.

Taberlet P, Coissac E, Hajibabaei M, Rieseberg LH. 2012. Environmental DNA. Mol Ecol 21: 1789-1793.

Therriault T, Orlova M, Docker M, MacIsaac HJ, Heath D. 2005. Invasion genetics of a freshwater mussel (Dreissena rostriformis bugensis) in eastern Europe: high gene flow and multiple introductions. Heredity 5: 1-8.

Valentini A, Taberlet P, Miaud C, et al. 2016. Next-generation monitoring of aquatic biodiversity using environmental DNA metabarcoding. Mol Ecol 25: 929-942.

Wagner A. 2014. Arrivée de Dreissena rostriformis bugensis (Andrusov, 1897) (Mollusca, Bivalvia, Dreissenidae), nouvelle espèce pour la faune d'Alsace. Folia Conchiliol 28: 19-22.

Wilson KA, Howell ET, Jackson DA. 2006. Replacement of zebra mussels by quagga mussels in the Canadian nearshore of Lake Ontario: the importance of substrate, round goby abundance, and upwelling frequency. $J$ Great Lakes Res 32: 11-28.

Woźniczka A, Wawrzyniak-Wydrowska B, Radziejewska T, Skrzypacz A. 2016. The quagga mussel (Dreissena rostriformis bugensis Andrusov, 1897) - another Ponto-Caspian dreissenid bivalve in the southern Baltic catchment: the first record from the Szczecin Lagoon. Oceanologia 58: 154-159.

Cite this article as: Prié V, Fruget J-F. 2017. Heading south: new records of the invasive quagga mussel Dreissena rostriformis bugensis (Andrusov, 1897) in France and further perspectives. Knowl. Manag. Aquat. Ecosyst., 418, 37. 